\title{
Cyanosis by methemoglobinemia in tadpoles of Cochranella granulosa (Anura: Centrolenidae)
}

\author{
Heinz Hoffmann \\ INASAG, Costa Rican Tadpole Research Center, Apartado 153, Barva-3011, Costa Rica; \\ heinz.hoffmann@gmx.com
}

Received 12-X-2009. Corrected 14-V-2010. Accepted 15-VI-2010.

\begin{abstract}
Tadpoles inhabit generally well oxygenated rivers and streams, nevertheless they were found in areas with limited oxygen availability inside the rivers. To assess this feature, I examined factors that influence centrolenid tadpole behaviour using Cochranella granulosa. The tadpoles were reared in well-oxygenated and hypoxic environments and their development, survivorship and growth were compared. The tadpoles in oxygenated water acquired a pale color, while tadpoles in hypoxic water grew faster and were bright red and more active. In the oxygenated water, the ammonium, which had its origin in the tadpoles' urine and feces, was oxidized to nitrate. In contrast, in the hypoxic treatment, the nitrogen compounds remained mainly as ammonium. Presumably, the nitrate in oxygenated water was secondarily reduced to nitrite inside the long intestine coils, because all symptoms in the tadpoles point to methemoglobinemia, which can occur when the nitrite passes through the intestine wall into the bloodstream, transforming the hemoglobin into methemoglobin. This could be checked by a blood test where the percentage of methemoglobin was $2.3 \%$ in the blood of tadpoles reared in hypoxic condition, while there was a $19.3 \%$ level of methemoglobin in the blood of tadpoles reared in oxygenated water. Together with the elevated content of methemoglobin, the growth of the tadpoles was delayed in oxygenated water, which had high nitrate content. The study about quantitative food-uptake showed that the tadpoles benefit more from the food in hypoxic water, although they spent there more energy moving around than the tadpoles living in oxygenated but nitrate-charged water. Rev. Biol. Trop. 58 (4): 1467-1478. Epub 2010 December 01.
\end{abstract}

Key words: tadpoles, Cochranella, Centrolenidae, hypoxia, ammonium, nitrite, nitrate, methemoglobin, methemoglobinemia, cyanosis.

I have reared the tadpoles of all species of Centrolenidae found in Costa Rica, but some failed to reach metamorphosis in part because of little knowledge of their larval ecology. While the tadpoles of some species (e.g., those in the genus Cochranella) are relatively easy to rear, others are extremely difficult to keep alive (Hoffmann 2010). In the present study, I examine factors that influence centrolenid tadpole survivorship using Cochranella granulosa.

Centrolenid tadpoles live in well-oxygenated rivers and streams, but they are described as lotic fossorial burrowers that live especially between the wet leaves and mud at the edges of streams (Villa \& Valerio 1982, McDiarmid \& Altig 1999, Savage 2002, Kubicki 2007). My observations with different bottom material in water containers suggest that tadpoles of some species prefer to sequester themselves in boulders and gravel of the sort found at the bottom of streams (unpublished data). This is an exceptionally low $\mathrm{O}_{2}$-habitat for a tadpole; therefore, one might expect that tadpoles inhabiting such an environment present specializations of their circulatory system to deal with low $\mathrm{O}_{2}$-concentration. Morphological studies suggest that 
the circulatory system of some centrolenid tadpoles is indeed adapted for life in hypoxic environment (Hoffmann 2010).

In the present paper, I explore the influence of low and high dissolved oxygen levels (DO) on the growth of tadpoles and the formation of their circulatory system. The investigation reveals a surprising response of $C$. granulosa tadpoles to being raised in normoxic and hypoxic water.

\section{MATERIALS AND METHODS}

General methods: Three experiments were run, all at an experimental site in the Highlands of Costa Rica at $1630 \mathrm{~m}$ above sea level $\left(10.08^{\circ}-84.1311^{\circ}\right)$. For the first experiment I used sibling tadpoles of $C$. granulosa from a clutch of eggs found on the border of a small watercourse in Quebrada Huacas, Guayacán, Province Puerto Limón $\left(10.04^{\circ}-83.53^{\circ}\right.$ at about $500 \mathrm{~m}$ above sea level). The other tadpoles for experiments two and three came from the Ombú Experimental Farm and nearby locations in the Caribbean lowlands of NorthEastern Costa Rica $\left(10.2637^{\circ}-83.6965^{\circ}\right.$ at $80 \mathrm{~m}$ above sea level). The bottom of the rearing tanks was covered with sand, gravel and cacao leaves. Cacao leaves are resistant to decomposition and with the stony material served as a rather inert material for the tadpoles to hide under. The tadpoles were fed ad libitum with dried leaves of Piper auritum.

The tadpoles were maintained in standing unchlorinated tap water. In the hypoxic water treatments (' $\mathrm{N}_{2}$ '- groups), the water was not changed. During the course of the experiments, the water was further deoxygenated by nitrogen injection. The containers of this treatment were then covered with two plastic sheets to maintain the low $\mathrm{O}_{2}$-concentration. The DO-concentration was checked with an YSI- 55 DO-meter three times daily in the first experiment and two times daily in next two experiments. When the oxygen concentration drifted out of the range for the targeted values of 1.00 to $1.75 \mathrm{ppm}$, in the $\mathrm{N}_{2}$-treatment the targeted $\mathrm{O}_{2}$-concentration was reestablished by either slightly opening the covering plastic sheets or by further nitrogenating. In normoxic-treatments (' $\mathrm{O}_{2}$ '-groups), the water was not changed, but oxygenated with an aquarium pump. The water of these two tadpole-groups deteriorated gradually because the water was not changed. Therefore, they are called 'wastewater'-treatments. The 'fresh water'-treatment in the Experiment two was also oxygenated, but additionally $80 \%$ of the water was changed twice a week.

Photographs were taken of each tadpole in ventral view with a digital camera type Coolpix 995 (NIKON). The body length and width of the tadpoles in all groups were taken with a screen caliper and an included scale in the photos.

Special methods and conditions of Experiment 1: The eggs of $C$. granulosa used in the first experiment hatched on September 11,2005 and the tadpoles were reared together in a small $(14 \times 9 \mathrm{~cm})$ container with about $5 \mathrm{~cm}$ water level. The experiment started on December 7, 2005, when the tadpoles were 87 days old, with two equal groups of ten tadpoles each. The containers for the two groups measured $30 \times 20 \times 15 \mathrm{~cm}$ and were filled with $5 \mathrm{~L}$ water each. The water in one container was oxygenated to an $\mathrm{O}_{2}$-concentration of $7.17 \pm 0.40 \mathrm{ppm}$ $(=79.6 \pm 4.1 \%)$. It will be called ' $\mathrm{O}_{2}$ '-treatment. The water of the second container was deoxygenated by nitrogen injection, which reduced the DO-concentration to $1.50 \pm 0.56 \mathrm{ppm}$ $(=16.7 \pm 6.1 \%)$ and is called ' $\mathrm{N}_{2}$ '-treatment. The temperature in both containers was nearly identical $\left(20.5 \pm 1.5^{\circ} \mathrm{C}\right.$ in the ' $\mathrm{O}_{2}$ '-treatment and $20.6 \pm 1.5^{\circ} \mathrm{C}$ in the ' $\mathrm{N}_{2}$ '-treatment). The final nitrate control was assessed with nitrate kits (CHEMetrics), the pH-measurement with the HANNA-pH-meter 'pHep' and the DO with the device specified above.

Special methods and conditions of Experiment 2: The second experiment started with C. granulosa tadpoles on January 3, 2008, which had been reared from September to December 2007 on the Ombú-Farm and then brought to the laboratory of the Experimental 
Station. Three groups of tadpoles were then kept there in containers of $29 \times 10 \times 11 \mathrm{~cm}$ admeasurements with two liters water each. Before the experiment started, on December 28, 2007, the tadpoles were photographed, measured and sorted in three equal groups of 10 tadpoles each. Additionally to the treatments described above, a further treatment was added in this experiment with water that was changed twice a week. Fig. 1 shows the temperature and DOlevels for the three tadpole groups in the 73 days of the experimental period. The temperatures of the three treatments in the sequence of the figure were $22.6 \pm 1.2^{\circ} \mathrm{C}, 22.8 \pm 1.1^{\circ} \mathrm{C}$ and $23.1 \pm 1.4^{\circ} \mathrm{C}$ respectively (see also section about general methods). The nitrate, nitrite and ammonium content of the water were checked with the colorimeter $\mathrm{HACH}$ 'DR/850'; the DO and the $\mathrm{pH}$ was assessed with the DO- and $\mathrm{pH}$ meter specified above.

Special methods and conditions of Experiment 3 with methemoglobin assessment: A third experiment with $C$. granulosa was performed from October 9 to December
9, 2008 with 12 tadpoles per treatment. The tadpoles were kept in the same conditions as in the second experiment. The food ingested by the tadpoles in the hypoxic and oxygenated water treatments was quantified in square centimeters of leaf mass. The DO-concentration in the hypoxic treatment was checked two times daily. Fig. 2 shows the temperature and DO-levels for the 61 experimental days for the hypoxic reared tadpoles. The control data for the two other treatments were taken eight times. For these treatments, with fresh water and oxygenated wastewater, the temperatures were $22.0 \pm 0.7^{\circ} \mathrm{C}$ and $22.2 \pm 0.6^{\circ} \mathrm{C}$, respectively, vs. $23.7 \pm 1.3^{\circ} \mathrm{C}$ in the hypoxic treatment. The averages of the corresponding DO-values were $6.49 \pm 0.10 \mathrm{ppm}$ and $6.44 \pm 0.12$ vs. $1.38 \pm 0.63 \mathrm{ppm}$. In the hypoxic water treatment, the temperature was $22.9 \pm 0.7^{\circ} \mathrm{C}$ in the morning at 7:09 $\pm 27^{\prime}$ and $24.5 \pm 1.2^{\circ} \mathrm{C}$ in the evening at $17: 14 \pm 18$ '; inversely, the DO-concentration in the hypoxic water treatment increased in the morning to $1.58 \pm 0.75 \mathrm{ppm}$ and declined in the evening to $1.18 \pm 0.39$. The nitrate, nitrite and ammonium contents of water were checked

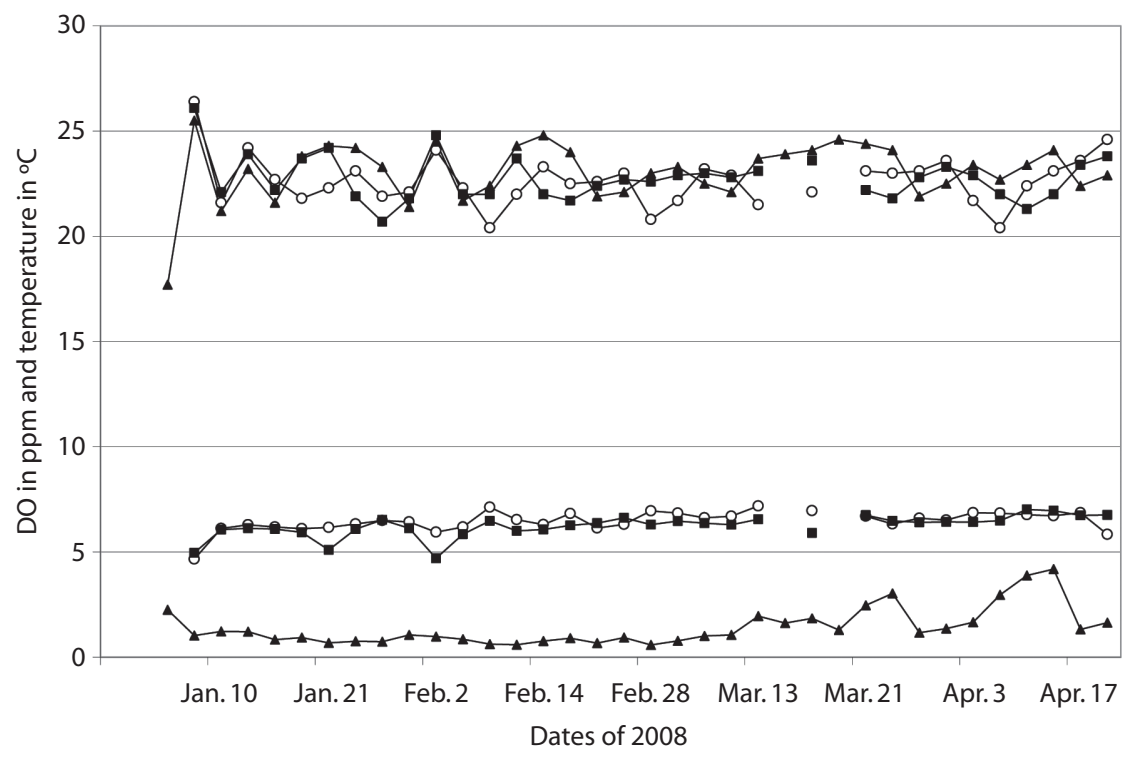

Fig. 1. Water temperature in ${ }^{\circ} \mathrm{C}$ (above) and DO in ppm (below) in hypoxic and oxygenated water treatments in Experiment 2. (Circles=water regularly changed; squares=oxygenated wastewater; triangles=hypoxic wastewater). 


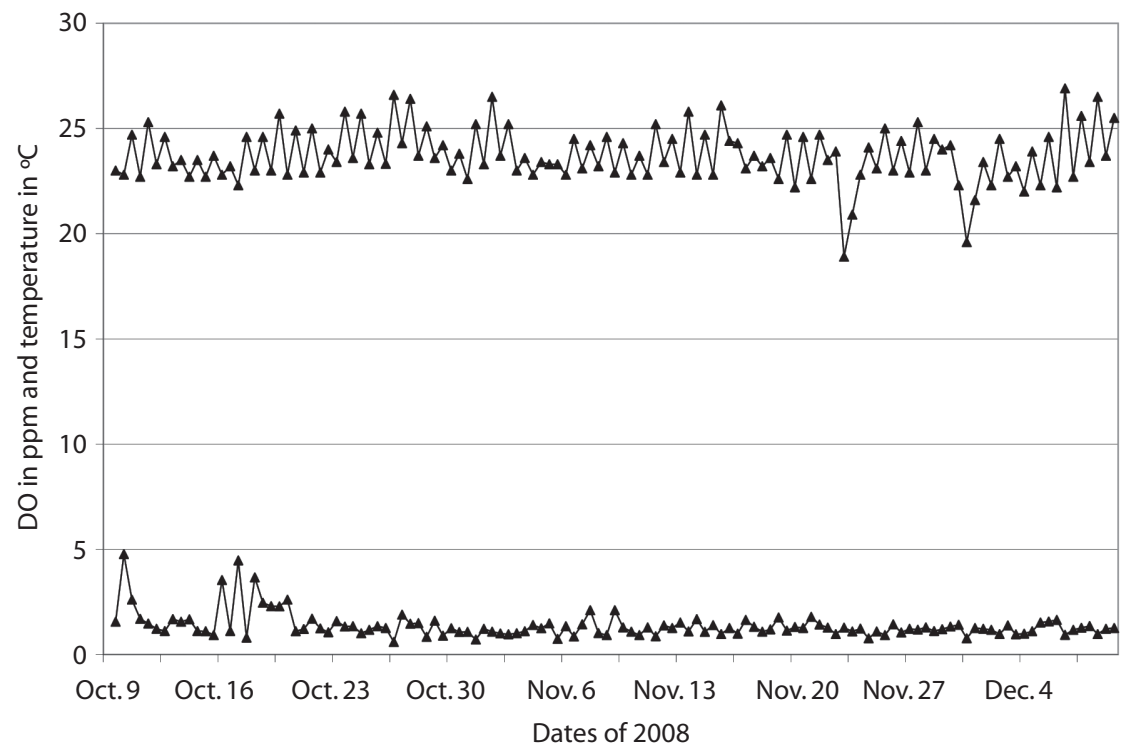

Fig. 2. Water temperature in ${ }^{\circ} \mathrm{C}$ (above) and DO in ppm (below) in hypoxic water treatment. See the averages for the oxygenated treatments in Experiment 3.

with the colorimeter $\mathrm{HACH}$ 'DR/850'. In this experiment, the content of nitrogen compounds in the water was concurrently assessed in the laboratory of PROCAME of the Universidad Nacional, ammonium and nitrite with a Jenway 6320D Spectrophotometer and nitrate with a DX-100 Ion Chromatograph and a DIONEX 4400 Integrator.

To determine the methemoglobin content, $0.2 \mathrm{ml}$ blood was needed from the tadpoles of each treatment. Due to the small quantity of blood that is extractable from a single tadpole, all 10 tadpoles of each treatment were sacrificed for a mixed blood sample of $0.2 \mathrm{ml}$ each. The tadpoles were first anaesthetized with 3-Aminobenzoic Acid Ethyl Ester (SIGMA Corp.). Then the blood was extracted using a $1 \mathrm{ml}$-insulin syringe from the sinus hyobranchialis. The methemoglobin concentration was assessed by the Centro de Investigación en Hematología y Trastornos Afines (CIHATA), department of the Universidad de Costa Rica following the method of Evelyn \& Malloy (1938).

\section{RESULTS}

Experiment 1: Tadpole development in hypoxic and oxygenated water: The tadpoles reacted differently during the one-month exposure in hypoxic vs. oxygenated water. The tadpoles of the $\mathrm{O}_{2}$-treatment in oxygenated water progressively reduced their activity over the whole period and stayed more often hidden below the cacao leaves and stones than the tadpoles of the $\mathrm{N}_{2}$-treatment in hypoxic water. The tadpoles of the $\mathrm{O}_{2}$-treatment acquired an increasingly pale color, whereas those of the $\mathrm{N}_{2}$-treatment were bright red and more active. Those tadpoles rasped the glass walls and came up to bite air when the DO-level occasionally sank markedly below 1ppm. On January 6, 2006, 30 days after initiating the two different treatments, all tadpoles were alive and all of the $\mathrm{N}_{2}$-treatment had a reddish skin well supplied with blood. In crass contrast to that appearance, all tadpoles of the $\mathrm{O}_{2}$-treatment had a uniformly violet colored central blood system and their skin was pale (Fig. 3). 


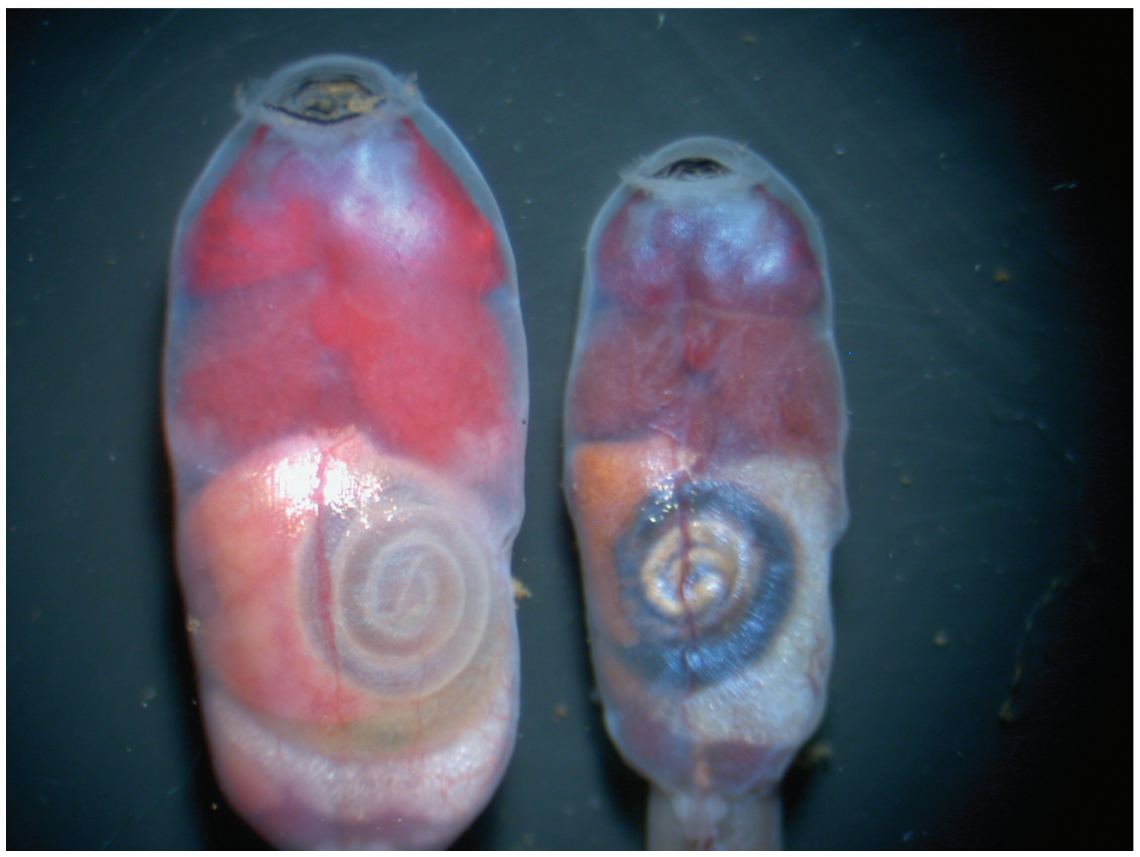

Fig. 3. Sibling tadpoles of Cochranella granulosa from hypoxic (left) and oxygenated water source (right).

Although the developmental stages expressed in Gosner-stages (Gosner 1960) were the same in both groups, the tadpoles differed in size (Table 1). In contrast to the substantial growth of the tadpoles in the $\mathrm{N}_{2}$-treatment, the tadpoles of the $\mathrm{O}_{2}$-treatment lost body mass due to a slight shrinking in length and a significant loss in body width.

The cyanosis symptoms observed in the tadpoles of the $\mathrm{O}_{2}$-treatment have noticeable resemblance to the well-known "Blue Baby Syndrome" in humans. This suggested the assessment of nitrate contents in both water sources, because a high nitrate content in water and baby food is one of the possible causes of that syndrome. Whereas the water of the healthy $\mathrm{N}_{2}$-group combined low DO-level with a low nitrate-level, the water of the $\mathrm{O}_{2}$-group was rich in oxygen and nitrate. These data drew attention to the potential effects of different concentrations of nitrogen compounds on tadpoles. This was explored in the next experiments with improved methods for detection and quantification of nitrogen compounds in the water.

Experiment 2: Tadpole development in hypoxic and oxygenated fresh- and wastewater: The development data of the tadpoles in the second experiment are shown in Table 2. At trial start, at December 28, 2007, there were no statistic differences between the groups of tadpoles. The unchanged water in the treatments 'Oxygenated water' and 'Hypoxic water' gradually deteriorated to 'wastewater'. About one month after trial start (February 2, 2008) and at March 17, 2008, the cyanosis symptoms were evident in the tadpoles of the two oxygenated water treatments, while the tadpoles reared in hypoxic water had healthy and bright red blood circulatory system. The body length and width were statistically greater for the tadpoles in hypoxic water and consequently for 'body length $\mathrm{x}$ width' too (Table 2).

The water analyses that followed immediately after the two tadpole assessments showed 
TABLE 1

Development of tadpoles of Cochranella granulosa reared during one month in hypoxic and oxygenated water

\begin{tabular}{lcccc}
\multicolumn{1}{c}{ Water treatment } & Tadpole stage & Body length $(\mathrm{mm})$ & Body width $(\mathrm{mm})$ & Body length $\mathrm{x}$ body $w$ \\
At experimental start & & & & \\
Hypoxic water & $28.70 \pm 1.77$ & $9.36 \pm 0.85$ & $4.16 \pm 0.59$ & $40.60 \pm 8.43$ \\
Oxygenated water & $28.50 \pm 1.84$ & $9.20 \pm 0.46$ & $4.22 \pm 0.30$ & $39.63 \pm 4.17$ \\
t-test & 0.807 & 0.620 & 0.755 & 0.916 \\
p-value & 0.428 & 0.542 & 0.458 & 0.370 \\
After 1 month & & & & $41.78 \pm 8.12$ \\
Hypoxic water & $34.00 \pm 4.74$ & $9.79 \pm 1.04$ & $4.24 \pm 0.40$ & $35.40 \pm 6.53$ \\
Oxygenated water & $33.50 \pm 5.38$ & $8.94 \pm 0.63$ & $3.93 \pm 0.51$ & 0.069 \\
t-test & 0.828 & 0.043 & 0.156 & 0.946 \\
p-value & 0.417 & 0.966 & 0.877 &
\end{tabular}

The index 'Body length $\mathrm{x}$ body width' was included as an indicator for the body mass.

TABLE 2

Appearance and measurements of tadpoles of Cochranella granulosa reared in different water qualities showing development parameters at three evaluation times

Evaluation at trial start 28.12.2007

$\begin{array}{lccccc}\text { Treatment } & \text { Stage } & \text { Gill color } & \text { Body length } & \text { Body width } & \text { Length } x \text { width } \\ \text { Fresh water } & 25.8 \pm 1.1 \mathrm{a} & \text { red } & 9.45 \pm 0.82 \mathrm{a} & 4.45 \pm 0.37 \mathrm{a} & 42.29 \pm 6.43 \mathrm{a} \\ \text { Oxygenated water } & 26.0 \pm 2.8 \mathrm{a} & \text { red } & 9.54 \pm 1.15 \mathrm{a} & 4.53 \pm 0.58 \mathrm{a} & 43.79 \pm 10.48 \mathrm{a} \\ \text { Hypoxic water } & 25.5 \pm 0.9 \mathrm{a} & \text { red } & 9.51 \pm 0.68 \mathrm{a} & 4.52 \pm 0.39 \mathrm{a} & 43.14 \pm 6.62 \mathrm{a} \\ \text { F } & 0.19 & & 0.02 & 0.09 & 0.09\end{array}$

Evaluation at 2.2.2008

$\begin{array}{lccccc}\text { Treatment } & \text { Stage } & \text { Gill color } & \text { Body length } & \text { Body width } & \text { Length x width } \\ \text { Fresh water } & 30.1 \pm 3.0 \mathrm{a} & \text { pale red } & 10.77 \pm 1.00 \mathrm{~b} & 5.10 \pm 0.48 \mathrm{~b} & 55.37 \pm 9.13 \mathrm{~b} \\ \text { Oxygenated water } & 29.2 \pm 2.4 \mathrm{a} & \text { pale red } & 10.65 \pm 0.88 \mathrm{~b} & 4.93 \pm 0.52 \mathrm{~b} & 52.87 \pm 9.38 \mathrm{~b} \\ \text { Hypoxic water } & 29.0 \pm 1.3 \mathrm{a} & \text { red } & 11.75 \pm 0.39 \mathrm{a} & 6.01 \pm 0.22 \mathrm{a} & 70.72 \pm 4.21 \mathrm{a} \\ \text { F } & 0.61 & & 5.68 & 18.32 & 14.70\end{array}$

Evaluation at 17.3.08

$\begin{array}{lccccc}\text { Treatment } & \text { Stage } & \text { Gill color } & \text { Body length } & \text { Body width } & \text { Length } \mathrm{x} \text { width } \\ \text { Fresh water } & 39.6 \pm 4.7 \mathrm{a} & \text { pale red } & 11.31 \pm 0.55 \mathrm{~b} & 5.06 \pm 1.02 \mathrm{~b} & 57.33 \pm 12.09 \mathrm{~b} \\ \text { Oxygenated water } & 40.1 \pm 2.2 \mathrm{a} & \text { pale red } & 11.67 \pm 0.86 \mathrm{~b} & 5.38 \pm 0.49 \mathrm{ab} & 62.76 \pm 7.94 \mathrm{~b} \\ \text { Hypoxic water } & 39.5 \pm 1.4 \mathrm{a} & \text { bright red } & 12.53 \pm 0.33 \mathrm{a} & 5.89 \pm 0.20 \mathrm{a} & 73.83 \pm 3.90 \mathrm{a} \\ \text { F } & 0.11 & & 9.57 & 3.95 & 9.23\end{array}$

Values with the same letter in the same column are not statistically different; Duncan-test, $\alpha=0.05$.

no differences in $\mathrm{pH}$ and temperature. The different concentrations of DO in the water set out for the treatments at the start were maintained during the experiment. Depending on the DOcontent in the water, the ammonium excreted by the tadpoles was transformed to a greater or lesser extent into nitrate. In contrast to the oxygenated wastewater, the hypoxic wastewater showed markedly lower concentration of nitrate $\left(\mathrm{NO}_{3}-\mathrm{N}\right)$ in both analyses. The nitrate 
content in the oxygenated wastewater increased strongly, especially in the second analysis. The ammonium contents $\left(\mathrm{NH}_{3}-\mathrm{N}\right)$ underwent changes during the last 1.5 months of the experiment and decreased in the hypoxic water presumably by the escape of gaseous nitrogen into the air. The formation of the nitrogen compounds in the 'fresh water' treatment was always altered due to the regular water changes (Table 3).

Experiment 3: Tadpole development in hypoxic and oxygenated wastewater with methemoglobin assessment: This experiment was started with the same three treatments described in Experiment 2. However, because of the loss of some tadpoles in the 'fresh water' treatment, this treatment was abandoned and the evaluations were restricted to the tadpoles reared in oxygenated and hypoxic wastewater.

The results were similar to those of Experiments 1 and 2: while the tadpoles in hypoxic water were healthy and grew well, the development of the tadpoles in the oxygenated water was stagnated (Table 4). Fig. 4 summarizes the data of the three experiments for changes in Gosner-stages, body lengths, body widths and product of body length $\mathrm{x}$ body width (BLxBW)

TABLE 3

Analysis from water samples in which tadpoles of Cochranella granulosa were reared in different DO-concentration

$\begin{array}{lccc}\text { Evaluation at Feb. 4, 08 } & \text { Fresh water } & \text { Oxygenated water } & \text { Hypoxic water } \\ \mathrm{DO} \text { ppm } & 6.1 \pm 0.5 & 5.8 \pm 0.6 & 0.9 \pm 0.2 \\ { }^{\circ} \mathrm{C} & 23.0 \pm 1.5 & 23.1 \pm 1.7 & 23.3 \pm 1.5 \\ \mathrm{pH} & 7.36 & 7.43 & 7.25 \\ \mathrm{NH}_{3}-\mathrm{N} & 0.10 & 0.10 & 0.81 \\ \mathrm{NO}_{3}-\mathrm{N} & 1.25 & 0.50 & 0.08 \\ \mathrm{NO}_{2}-\mathrm{N} & 0.045 & 0.029 & 0.052\end{array}$

$\begin{array}{lccc}\text { Mar. 17, } & \text { Fresh water } & \text { Oxygenated water } & \text { Hypoxic water } \\ \mathrm{DO} \text { ppm } & 6.7 \pm 0.4 & 6.3 \pm 0.2 & 1.0 \pm 0.5 \\ { }^{\circ} \mathrm{C} & 22.2 \pm 0.9 & 22.7 \pm 0.6 & 23.1 \pm 1.0 \\ \mathrm{pH} & 6.82 & 7.36 & 7.04 \\ \mathrm{NH}_{3}-\mathrm{N} & 0.06 & 0.16 & 0.06 \\ \mathrm{NO}_{3}-\mathrm{N} & 1.11 & 6.21 & 0.08 \\ \mathrm{NO}_{2}-\mathrm{N} & 0.003 & 0.021 & 0.005\end{array}$

TABLE 4

Measurements on tadpoles of Cochranella granulosa reared in oxygenated and hypoxic water

\begin{tabular}{lcccc}
\multicolumn{1}{c}{ Water treatment } & Tadpole stage & Body length $(\mathrm{mm})$ & Body width $(\mathrm{mm})$ & Body length x body width \\
At experimental start (9.10.2008) & & & & \\
Hypoxic water & $28.0 \pm 3,4$ & $8.92 \pm 1,02$ & $3.94 \pm 0.36$ & $35.48 \pm 6.95$ \\
Oxygenated water & $27.8 \pm 3.0$ & $8.81 \pm 0.85$ & $3.86 \pm 0,37$ & $36.16 \pm 7.32$ \\
t-test & 0.4838 & 0.3408 & 0.5474 & 0.2351 \\
p-value & 0.6380 & 0.7397 & 0.5896 & 0.8163 \\
After 1 month (10.11.2008) & & & & $42.55 \pm 9.27$ \\
Hypoxic water & $31.7 \pm 6.2$ & $10.00 \pm 1.22$ & $4.21 \pm 0.46$ & $35.94 \pm 6.43$ \\
Oxygenated water & $30.8 \pm 6.6$ & $9.25 \pm 1.00$ & $3.86 \pm 0.33$ & 2.0272 \\
t-test & 0.3194 & 1.6444 & 2.1195 & 0.0549 \\
p-value & 0.7524 & 0.1143 & 0.0456 &
\end{tabular}



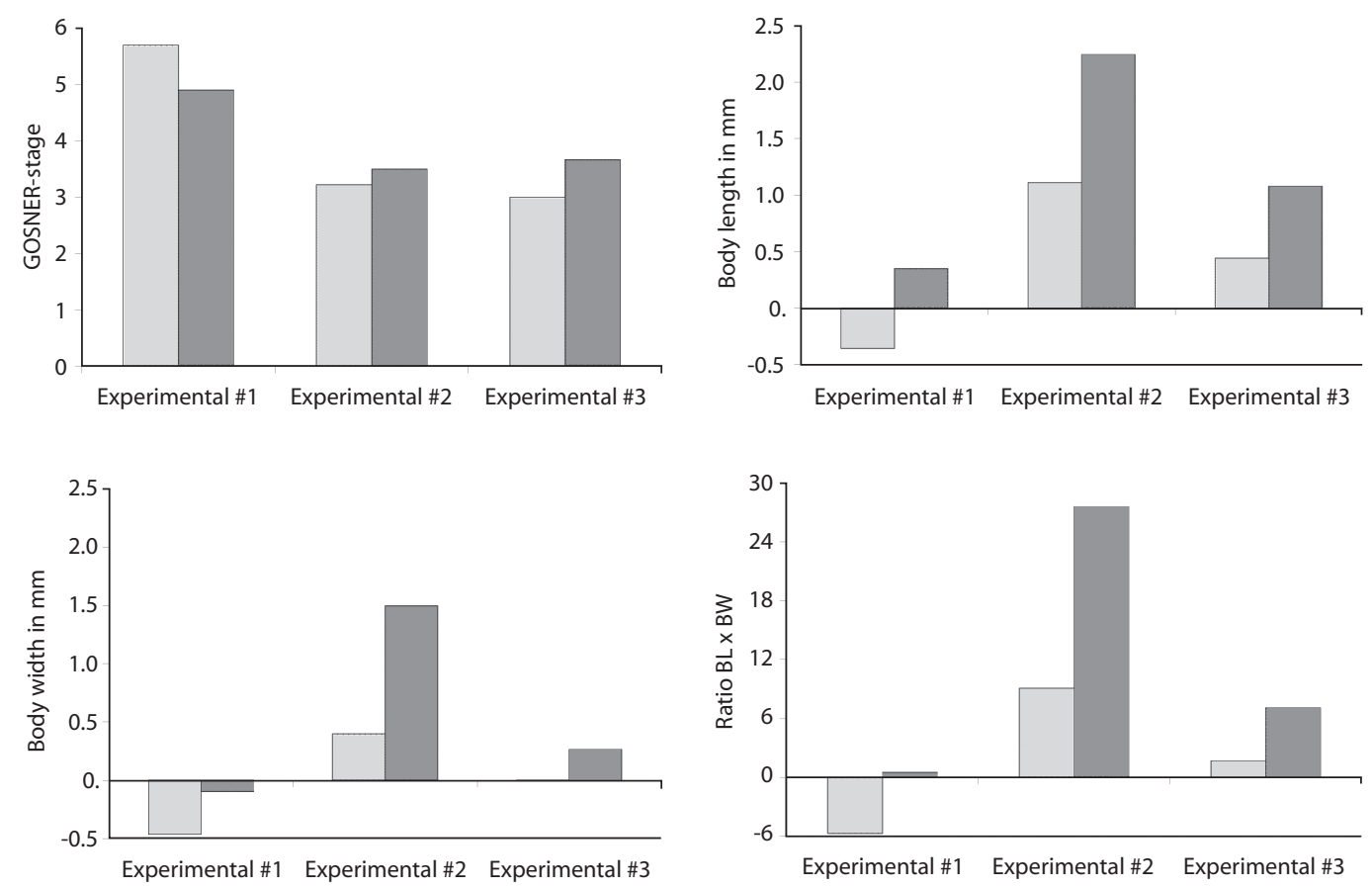

Fig. 4. Relative changes in Gosner-stages of the tadpoles of Cochranella granulosa, their body lengths, body widths and the product of body length $\mathrm{x}$ body width (BLxBW) during one month exposition to oxygenated (light gray bars) and hypoxic water (dark gray bars).

during the experimental period of one month. While the development expressed in Gosner-stages continued similarly in both water qualities, the growth of the tadpoles in the oxygenated water was inhibited relatively in relation to the tadpoles in the hypoxic water (and absolutely in the first experiment). The tadpoles reared in oxygenated water fed $544 \mathrm{~cm}^{2}$ of leaf mass while the tadpoles in hypoxic water fed $512 \mathrm{~cm}^{2}$ during the experimental period.

Water analyses were performed two times: On November 15, 2008, at 37 days after trial start, and on December 11, 2008, after 63 days (Table 5). The second analysis was replicated with other methods in the PROMER-Laboratory of the Universidad Nacional. Despite the numeric differences between the two analyses, they show the same tendency: while the amount of ammonium is markedly higher in hypoxic than in oxygenated water, nitrate prevailed in oxygenated water and the nitrite concentration is low in both samples.

While the blood extracted from the tadpoles reared in hypoxic water had a bright red color, the blood of the tadpoles from the oxygenated water had acquired a reddish chocolate tint. The latter tadpoles showed the general symptoms of severe cyanosis. Furthermore, the percentage of methemoglobin in the blood of the hypoxic-reared tadpoles was $2.3 \%$, contrasting with $19.3 \%$ in the blood of the tadpoles reared in oxygenated water. In humans and other vertebrate organisms, methemoglobin levels higher than $15 \%$ is a serious health hazard (Seger \& Hantsch 2001).

\section{DISCUSSION}

There is much variation in nitrate tolerance for tadpoles of different species. Some authors 


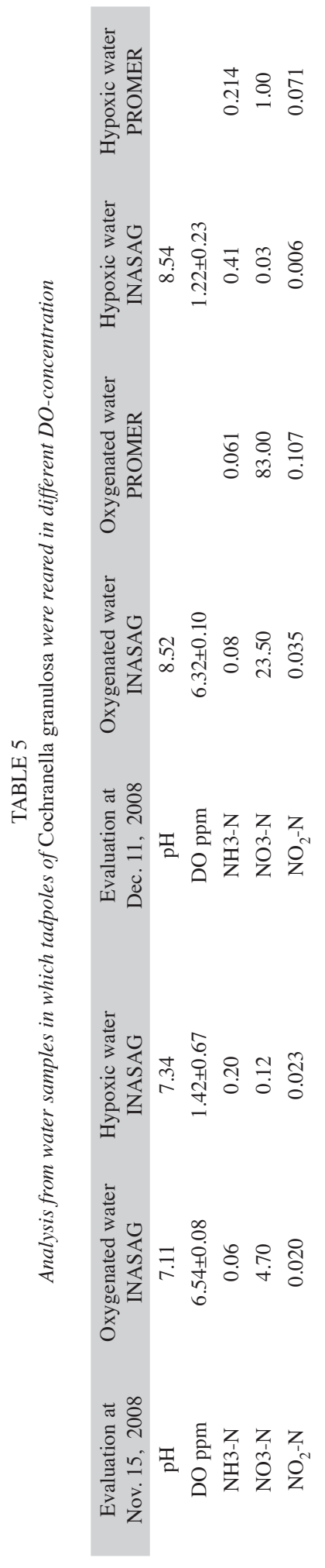

report no damage to tadpoles reared in water high in nitrate content (Langan 2003, Allran \& Karasov 2000). Hecnar (1995), however, found considerable differences between the tadpoles of Pseudacris triseriata and Rana pipiens with lower survival rates in both compared to the more resistant Rana clamitans tadpoles.

Such interspecific variation reported in numerous publications may reflect genetic differences among species. It may also reflect differences in experimental design such as the type of nitrogen pollution assessed or/and differences in other water quality parameters, like pH. Marco (2002) and Griffis-Kyle (2005) pointed out the important fact that sensitivity of tadpoles to nitrates decreases notably with the age of the tadpoles. Many researchers work with older tadpoles where the nitrogen pollution has a relatively limited impact on tadpole survival. In contrast, in nature, embryonic or hatchling stages sometimes die when exposed to the same nitrogen concentrations that are used for experiments with larger tadpoles. All these factors may account for why some species have been reported to be more resistant than others to high nitrogen concentrations. In the experiments reported herein, I tried to point to other ecological factor: the content of dissolved oxygen (DO) in the water and the corresponding production of nitrogenous substances as well as the probable indirect influence of nitrate on tadpole health.

The oxygen uptake occurs mainly in gills and skin. In contact with the blood, oxygen is charged by the ${ }^{++} \mathrm{Fe}$ ions in the hemoglobin molecules and is transported throughout the body of the tadpoles. However in the presence of nitrite, the ferrous hemoglobin (=++Fe $\mathrm{Hgl})$ will be oxidized into ferric methemoglobin $(=+++\mathrm{Fe})$. Through that process, the nitrite ion occupies the place of the oxygen and this renders the hemoglobin molecule incapable of transporting and releasing oxygen to the tissues. This phenomenon is widely known in human medicine and described as methemoglobin cyanosis or methemoglobinemia. Normally, about $1 \%$ of the total hemoglobin in the blood is present in methemoglobin form. 
Markedly higher concentrations are dangerous to vertebrates (Knobeloch et al. 2000, Lee \& Ferguson 2009).

The question was where the nitrite in the tadpoles comes from, if it is found only in trace amounts in the water. In the unchanged water, the urine and excrements of the tadpoles as well as the mellow plant substances contain high amounts of ammonium. Continuous nitrification of the ammonium source takes place by bacterial activity that produces nitrite in the first step and finally nitrate due to the high DOconcentration in the oxygenated water. Nevertheless, in this process, the water maintains only low levels of the transitory highly toxic nitrite as it is checked by the water analyses for the experiments presented here. In these experiments, the toxic impact in tadpoles occurred solely when they lived in water with high nitrate concentration. However, that does not prove that the exogenous nitrate in the water is itself the dangerous agent. Jensen (1995) pointed out that nitrate poisoning in domestic animals, such as cattle and sheep, was caused by conversion of nitrate to nitrite by gut microorganisms. Horses are extremely susceptible because of their large caecum (the bacterial conversion of nitrate to nitrite in horses takes place primarily in this intestinal pocket).

A similar process presumably occurs in the large intestine coils of tadpoles, where nitrate is the primary if not only oxygen source for anaerobic gut bacteria, which reduce nitrate to nitrite for their oxygen needs. After that, the nitrite enters through the intestine wall into the blood system, transforming the hemoglobin in methemoglobin thereby blocking the uptake and transportation of oxygen in the blood, as above described. Although the water was abundantly oxygenated in the high DO-treatments of the experiments, the tadpoles suffocated by deficient oxygen assimilation in the blood. In addition, Fig. 3 suggests that the blood system of the intestine is especially damaged because it is the first receptor of the nitrite. Therefore, I hypothesize that the toxic nitrite in the guts of the tadpoles is product of endogenous transformation of nitrate, meanwhile the nitrite concentration in the water stay at low levels. The risk to tadpoles of nitrite poisoning from this source may vary with intestinal passage rates which are themselves likely influenced by the specific intestine length, among other causes. This may explain why tadpoles that live in well oxygenated but nitrate-charged water show symptoms of extreme anoxia and why methemoglobinemia is not necessarily due to a direct uptake of water-borne nitrite through the gills.

Various observations, like the cyanosis symptoms for the whole body, the reddish chocolate color of the blood and the high level of methemoglobin, all point to methemoglobinemia in the tadpoles reared in oxygenated water, but ultimately caused by the high nitrate concentration in the water. This process may account for the general weakening of water organisms, such as certain tadpoles, when the nitrate level in the surrounding water rises.

In contrast, the tadpoles of $C$. granulosa develop well in hypoxic condition due to the inhibition of the transformation of ammonium to nitrate. It would be a challenge to investigate if hypoxic conditions stimulate per se red blood cells production and consequently more hemoglobin. While the tadpoles reared during the experimental period in oxygenated water ate up leaf masses of $544 \mathrm{~cm}^{2}$ of $P$. auritum, in hypoxic water, the same number of tadpoles grew better and was healthier than the first ones, but ate only $512 \mathrm{~cm}^{2}$. Therefore, although the tadpoles in hypoxic water spent more energy moving about, they profited quite more from the food than the tadpoles living in oxygenated but nitrate-charged water

\section{ACKNOWLEDGMENTS}

I am greatly indebted to the following institutions and persons: Javier Guevara Sequeira of MINAET (SINAC) provided the permits for investigation. My assistant Miguel Angel Alfaro Herrera attended the tadpoles. With Richard Wassersug, I shared information and together with Johannes Köhler they helped edit the manuscript. Jorge Herrera Murillo, coordinator of 
the Laboratory of Ambient Analyses (Universidad Nacional) supported this study with water analyses. This study was improved decisively by the analysis of methemoglobin concentration in the tadpoles. Those analyses were done in the Centro de Investigación en Hematología y Trastornos Afines (CIHATA) of the Universidad de Costa Rica, with the generous permit of Walter Rodríguez. I have received with appreciation the comments of three unknown reviewers that have improved the manuscript in some important details.

\section{RESUMEN}

Los renacuajos por lo general viven en ríos y arroyos bien oxigenados, sin embargo, como han sido encontrados en áreas con disponibilidad de oxígeno limitada en los ríos, se estudió como influye este factor en su comportamiento. Renacuajos de Cochranella granulosa fueron criados en ambientes bien oxigenados y de hipoxia para comparar su desarrollo, supervivencia y crecimiento. En el agua que no fue cambiada durante al menos un mes, los renacuajos mostraron diferencias en su desarrollo cuando vivían en agua hipóxica u oxigenada. Los renacuajos en el agua aireada tenían un color pálido, mientras que en la hipóxica fueron más activos y de un color rojo brillante. En el agua hipóxica, el nitrógeno que se originó de la orina y las heces de los renacuajos se mantuvo principalmente en forma de amonio; en cambio, el amonio fue oxidado a nitrato en el agua aireada. Presumiblemente, el nitrato en el agua oxigenada se redujo secundariamente a nitrito dentro del intestino, ya que todos los síntomas en los renacuajos que vivían en esta agua apuntaron a una metahemoglobinemia, que se produce cuando el nitrito pasa a través de la pared del intestino a la corriente sanguínea transformando la hemoglobina en metahemoglobina. Esto pudo comprobarse mediante un análisis sanguíneo en donde el porcentaje de metahemoglobina fue del $2.3 \%$ en la sangre de los renacuajos criados en condición hipóxica y de un $19.3 \%$ de metahemoglobina en aquellos criados en agua aireada. En la misma forma en que la metahemoglobina aumenta en la sangre de los renacuajos que viven en agua oxigenada, su crecimiento disminuye en agua con alto contenido de nitrato. El estudio cuantitativo de la ingestión de nutrientes mostró que el crecimiento de los renacuajos se beneficia más de los alimentos en agua hipóxica, a pesar de que los renacuajos son más activos en sus movimientos que los que viven en agua oxigenada pero cargada de nitratos.

Palabras clave: renacuajos, Cochranella, Centrolenidae, hipoxia, amonio, nitrito, nitrato, metahemoglobina, metahemoglobinemia, cianosis.

\section{REFERENCES}

Allran, J.W. \& W.H. Karasov. 2000. Effects of atrazine and nitrate on Northern leopard frog (Rana pipiens) larvae exposed in the laboratory from posthatch through metamorphosis. Environ. Toxicol. \& Chem. 19: $2850-2855$.

Evelyn, K.A. \& H.T. Malloy. 1938. Microdetermination of oxyhemoglobin, methemoglobin and sulfhemoglobin in a single sample of blood. J. Biol. Chem. 126: 655-662.

Griffis-Kyle, K.L. 2005. Ontogenic delays in effects of nitrite exposure on Tiger salamanders (Ambystoma tigrinum tigrinum) and Wood frogs (Rana sylvatica). Environ. Toxicol. \& Chem. 24: 1523-1527.

Gosner, K.L. 1960. A simplified Table for stating anuran embryos and larvae with notes on identification. Herpetologica 16: 183-190

Hecnar, S.J. 1995. Acute and chronic toxicity of Ammonium fertilizer to amphibians from southern Ontario. Environ. Toxicol. \& Chem. 14: 2131-2137.

Hoffmann, H. 2010. The glassfrog tadpoles of Costa Rica (Anura: Centrolenidae): A study of morphology. Abh. Senckenberg Ges. Naturforsch. 567: 1-78.

Jensen, F.B. 1995. Uptake and effects of nitrate and nitrite in animals, p. 289-303. In P.J. Walsh \& P. Wright (eds.). Nitrogen Metabolism and Excretion. CRC, Boca Raton, Florida, USA.

Knobeloch, L., B. Salna, A. Hogan, J. Postle \& H. Anderson. 2000. Blue Babies and Nitrate-Contaminated Well Water. Environ. Health Perspect. 108: 675-678.

Kubicki, B. 2007. Ranas de vidrio. Glass Frogs. Instituto Nacional de Biodiversidad, INBio, San José, Costa Rica.

Langan, E.M. 2003. Sublethal effects of sodium nitrate on developmental rate and body length in Southern toad (Bufo terrestris) tadpoles. Master Thesis, University of Florida, Florida, USA.

Lee, D.C. \& K.L. Ferguson. 2009. Methemoglobinemia. EMedicine, Omaha, Nebraska, USA. (Accessed July 15 2009, http://emedicine.medscape.com/ article/815613-overview).

Marco, A. 2002. Impacto de la contaminación ambiental en los anfibios: enfoque aplicado a espacios protegidos de montaña, p. 65-72. In Actas de las III Jornadas Científicas del Parque Natural de Peñalara y del Valle 
del Paular. Biodiversidad: investigación, conservación y seguimiento. Madrid, Spain.

McDiarmid, R.W. \& R. Altig. 1999. Tadpoles: The Biology of Anura Larvae. The University of Chicago, Chicago and London.

Savage, J.M. 2002. The Amphibians and Reptiles of Costa Rica. The University of Chicago, Chicago and London.
Seger, D.L. \& C.E. Hantsch. 2001. Methemoglobin-Forming Compounds, p. 727-733. In J. Sullivan Jr. \& G.R. Krieger (eds.). Clinical environmental health and toxic exposures. Lippincott Williams \& Wilkins, Baltimore, Maryland, USA.

Villa, J. \& C.E. Valerio. 1982. Red, white and brown. Preliminary observations on the color of the centrolenid tadpole (Amphibia: Anura: Centrolenidae). Brenesia 19: 1-16. 